Article

\title{
Sustainability Reporting in the upstream oil and gas industry between awards and violations: A systematic literature review, evidence from Indonesia
}

\author{
Febrian Kwarto 1,2, Nunuy Nurafiah 2, Harry Suharman, and Muhammad Dahlan 2, * \\ 1 Universitas Mercu Buana Jakarta Indonesia1. \\ 2 Universitas Padjadjaran Bandung Indonesia 2; nunuy@unpad.ac.id; harry.suharman@unpad.ac.id; muham- \\ mad.dahlan@unpad.ac.id \\ * Correspondence: febrian kwarto@mercubuana.ac.id
}

\begin{abstract}
The operating activities of the upstream oil and gas industry directly impact the environment. This industry faces significant social challenges and directly impacts the environment. Many Reputable international sustainability institutions organize sustainability awards. However, community conditions do not have a positive impact on sustainability practices. There are various serious violations related to sustainability, environmental pollution, multiple cases of corruption, human rights, and other violations. In contrast, the companies receiving this award also received inspection findings of violations committed by The Audit Board of the Republic of Indonesia. This study uses critical discourse analysis that begins with phenomena related to violations of sustainability reporting from scientific journals and other references using a systematic literature review approach over the last ten years. It produces a critical paradigm that is not value-free, which is the basis for framing thought utilizing the theory of hegemony. The results of this study indicate that the upstream oil and gas industries are obliged to implement Corporate Social Responsibility (CSR) practices and Sustainability Reports (SR), has biased factors that are contrary to the sustainability concept and are not under the sustainability award based on evidence obtained from the stages of manuscript analysis with systematic literature review
\end{abstract}

Keywords: sustainability reporting, critical paradigm, upstream oil, and gas

1. Introduction

Accounting research on social and environmental topics has evolved over the last few decades as a distinct field of business research [1]. One of the focuses is Sustainability Reporting (SR), a report that consists of data related to a company's environmental and social practices and their impacts.

Public companies publish sustainability reports (SR), also known as corporate social responsibility reports, containing unusual values with multidimensional aspects such as information of the environment, human rights, employment practices, employability, product responsibility, society, and quantitative and qualitative data publicly available[2]

The global financial crisis of recent years has highlighted the cause of one of the problems due to the absence of CSR [3]. In managing each impact of the company's activities, including finance and the environment, it is necessary to have sustainability rooted in togetherness which refers to the responsibility of every individual involved in the company's activities as the basis for global corporate responsibility [4]

Corporate social responsibility of the upstream oil and gas industry faces significant environmental and social challenges such as pollution issues, relations with surrounding communities, compliance issues with regulatory and framework requirements, 
various institutional standards with different industries[5] because CSR practices and reporting provide a strategic framework for achieving a holistic reassessment of company performance [6]

The oil and gas sector has a significant impact on sustainable development. Due to the nature of this activity which causes a high risk, companies must continuously reduce the significance of their adverse effects on the environment and humans.[7]. Oil and gas companies must submit information related to environmental impact activities caused by operational activities, and companies can communicate CSR through the Sustainability Report [8]. But in reality, the CSR reports contradict the principles of GRI standards, do not disclose $90 \%$ of negative information, or only report part of it [9]

Indonesia is one of the largest oil-producing countries globally and has the most oil and gas wells spread throughout the Indonesian archipelago. Various reputable oil and gas companies in the world are competing for exploration rights to these wells. The followings are the distribution of the presence of oil and gas wells throughout the Indonesian archipelago

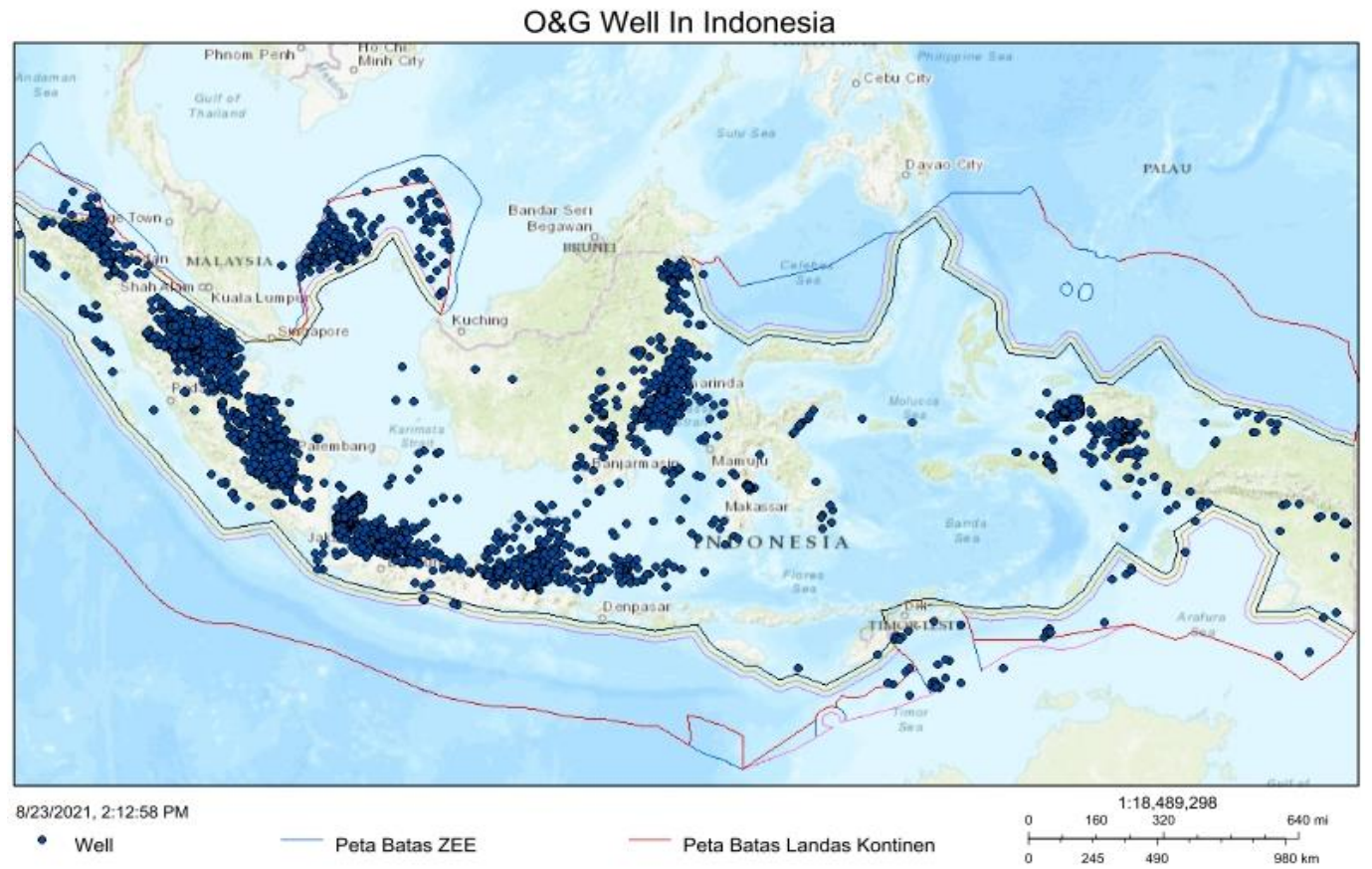

Source: https://geoportal.esdm.go.id/migas/

Figure 1. Distribution of oil and gas wells in the Indonesian archipelago

Oil and gas production has a long history in Indonesia. Since discovering the first oil in North Sumatra in 1885, Indonesia has become a pioneer internationally, among others, in developing the Production Sharing Contract (PSC) model and the commercialization of Liquefied Natural Gas (LNG). At the end of 2018, Indonesia's oil reserves were recorded at 3.2 billion barrels and were ranked 11th in terms of world gas production [10]. The following are oil and gas companies that have working areas as oil and gas producers in Indonesia 


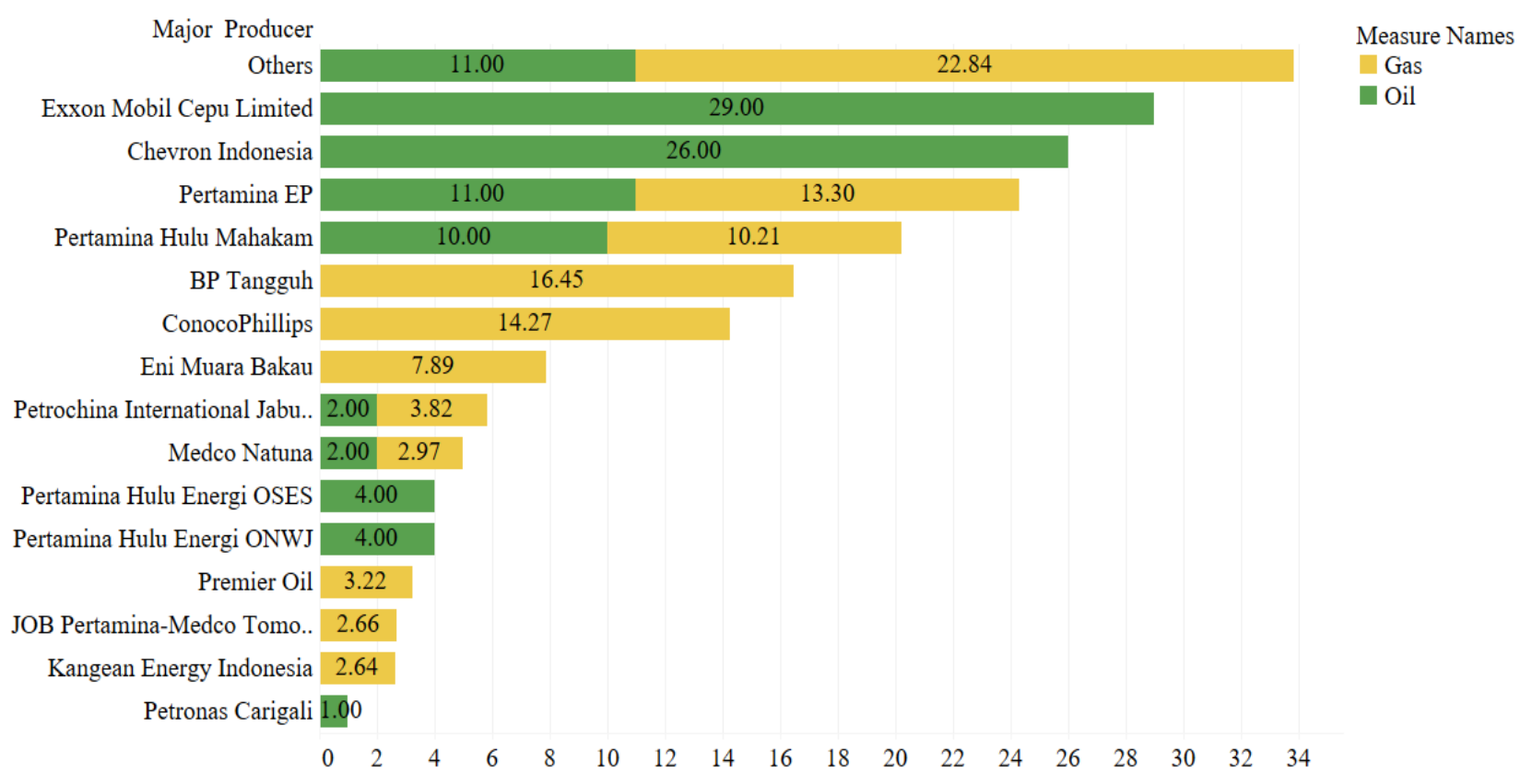

Source: PwC [11]

Figure 2. Oil and Gas major producers in Indonesia

On the one hand, development in the oil and gas industry benefits the welfare of the people, but on the other hand, it also makes waste that can pollute the environment and harm humans. The Indonesian government has given strict rules regarding the obligations of the oil and gas sector industry to preserve the environment. The regulation is article 74 paragraph (1) of Law no. 40 of 2007 concerning Limited Liability Companies, which reads as follows: "Companies that carry out their business activities in the field of and or related to natural resources are obliged to carry out social and environmental responsibilities." [12] Companies can disclose social responsibilities that cover these various aspects in the form of sustainability reporting.

However, in reality, most of the environmental disclosures related to specific cultural and socio-economic ecological influences in the sustainability reports of Oil and Gas companies are given only limited consideration [13]. In addition, there are many findings of SR reporting practices that are not under the conditions of the community where the industry carries out the exploration and mining process [14-16], such as the ExxonMobil case in Lhokseumawe Aceh, Indonesia, which was involved in human rights violations [17]. In addition, there are also cases of corruption in CSR funds at the oil and gas company Pertamina amounting to 126 billion out of a total project of 256 billion.[18]. Also, the land grabbing case in the Cepu Block case in Bojonegoro, Indonesia, by ExxonMobil involved local profit-seeking elites, including government officials, community elites, and social movement leaders.[19]

However, other facts are that these global upstream oil and gas companies in Indonesia have received various awards related to achievements in sustainability. These awards include in 2014 as many as 71 oil \& gas contractors (KKKS), which received three Sustainability Reporting Awards 2014 for the 2013 Sustainability Report, which was held by the National Center for Sustainability Reporting (NCSR) [20]. Also, in 2021, at the Asia Sustainability Reporting Awards (ASRA), a non-profit sustainability organization based in Singapore in partnership with the Global Reporting Initiative (GRI), International Integrated Reporting Council (IIRC), EcoVadis, CDP, S\&P Global (CSA / Dow Jones Sustainability Index), Sustainability Accounting Standards Board (SASB) and AccountAbility (AA1000) awarded Pertamina as a company that succeeded in disclosing sustainability performance information during 2020, uphold the commitment to maintain 
sustainable business prospects by prioritizing the balance and preservation of nature, protecting the environment, and contributing to the independence of the community [21]

The two sides of this reality are in stark contrast between the findings of violations related to sustainability reporting and the achievement of awards in the field of sustainability. This contrast happens because there are several bias factors in CSR practices and SR reporting, where companies do not fully understand and implement the fundamental CSR concept.

SR reports are more likely to be a formality to get a positive image in the sight of the community. CSR practices are carried out in general activities and do not focus on community needs because they are only based on company interests and are often unsustainable [22]

\section{Research methods}

\subsection{Research paradigm}

This research is a critical paradigm that aims to fight for researchers' ideas to bring about substantial changes in society because the critical paradigm is not only understanding and interpreting but has the characteristics of a desire to apply knowledge and the belief that research is not value-free.[23] Critical paradigm point relies on reality associated with specific values, namely the closeness between the researcher and the object under study [24]. Therefore, the main objective of the critical paradigm is the liberation of the value of domination from an oppressed group, the context in this study is the corporate group as a group that carries out its operational activities and CSR activities on the environment and society as a group that gets a direct impact from these activities

The critical paradigm in this study views the previously disclosed phenomena that should not have occurred in the implementation of CSR and SR reporting in the upstream oil and gas industry, including deviations and violations of rules and environmental destruction that result in losses to the surrounding community. This critical paradigm refers to the essential epistemology of Marxism [24]. Furthermore, the Frankfurt group, such as Adorno, Herbert Marcuse, and Habermas, popularized it in a critical theory that explains, considers, and is willing to change and ready to be practical. This study aims to describe the factors that can be biased in the sustainable reporting of upstream oil and gas industry companies by revealing the contrast phenomenon between awards and sustainability violations. This situation is in complete disharmony, full of conflict, and must show how the reality of the condition should be.

\subsection{Critical Discourses Analysis}

This study uses critical discourse analysis as a specific methodological approach that forms the basis for the critical theory used in this study. Critical discourse analysis tries to explain the content of the text and its context or history about a theme or issue created in the text. This analysis aims to find out how the dominant group is more in control. On the other hand, other groups whose low positions tend to be objects and are not continuously described [25].

Discourse analysis is a way to find evidence in a text or show part of the text as data findings to answer research problems. Critical discourse analysis is involved with various discourse analyses and critical social theory $[25,26]$. This research explains CSR practices and SR reporting in text and the fundamental thoughts of CSR discourse that appear as the image of upstream oil and gas companies campaigning to save the earth due to the damage done by the production process. Award achievement promotion for SR reporting. In conducting this discourse analysis, the researcher uses a systematic literature review stage approach to ensure that the stages of manuscript analysis carried out can be appropriately presented. 


\subsection{Systematic Literature Review}

Systematic Literature Review (SLR) is a systematic way to collect, critically evaluate, integrate and present findings from various research studies on research or topics of interest. The SLR provides a way to assess the quality of existing evidence on a question or issue claim. SLR offers a broader and more accurate level of understanding than traditional literature [27]. SLR synthesizes relevant research results so that the facts presented to interested parties will be more comprehensive and balanced. This study follows systematic literature review guidelines, referring to general principles guided by research questions and a systematic approach.[28,29]

CSR practices and SR reporting as research objects with SLR by conducting a scientific search for the last ten years related to CSR practices and SR reporting with the following criteria

Table 1. Determination of Criteria for SLR Research Objects

\begin{tabular}{ll}
\hline Issue & Selection Criteria \\
\hline Publication Type & Scholarly Journals \\
Publication Year & 2010-2020 \\
Language & English \\
Availability & Full Text \\
Research Methodology & Qualitative and Quantitative \\
Keywords Search & CSR, Sustainability Report, Upstream Oil, and Gas \\
\hline
\end{tabular}

Researchers searched five scientific journal databases, namely Science Direct, ProQuest, Taylor \& Francis, Emerald Insight, and Ebsco Host. Based on the research object specified in this study, as shown in the table above, the researcher does not limit it to the oil and gas industry keywords in the Indonesian territory. This action is due to the number of scientific papers related to CSR, SR Upstream oil, and gas, with the Indonesian territory object still being very limited as an object of research for international publications within ten years criteria of research time determination

Specifically, upstream oil and gas industry companies as objects in this study are companies that carry out CSR practices and SR reporting. These companies have collaborations and affiliations with upstream oil and gas industry companies in Indonesia. This category includes the Indonesian upstream oil and gas company Pertamina as the object of literature review research with this systematic review.

This review follows the criteria in table 1 above, namely the publication of international scientific articles that discuss CSR practices and SR reporting in upstream oil and gas companies. Consequently, all upstream oil and gas companies discussed in the provisions of this publication become the target criteria in the initial search for this method

Implementation of the analysis with Systematic Literature Review with the following stages: 
- $\quad$ Taylor \& Francis $=45$

- $\quad$ Emerald Insight $=20$

- $\quad$ ProQuest $=47$

- $\quad$ Science Direct $=54$

- $\quad$ EBSCO Host $=36$
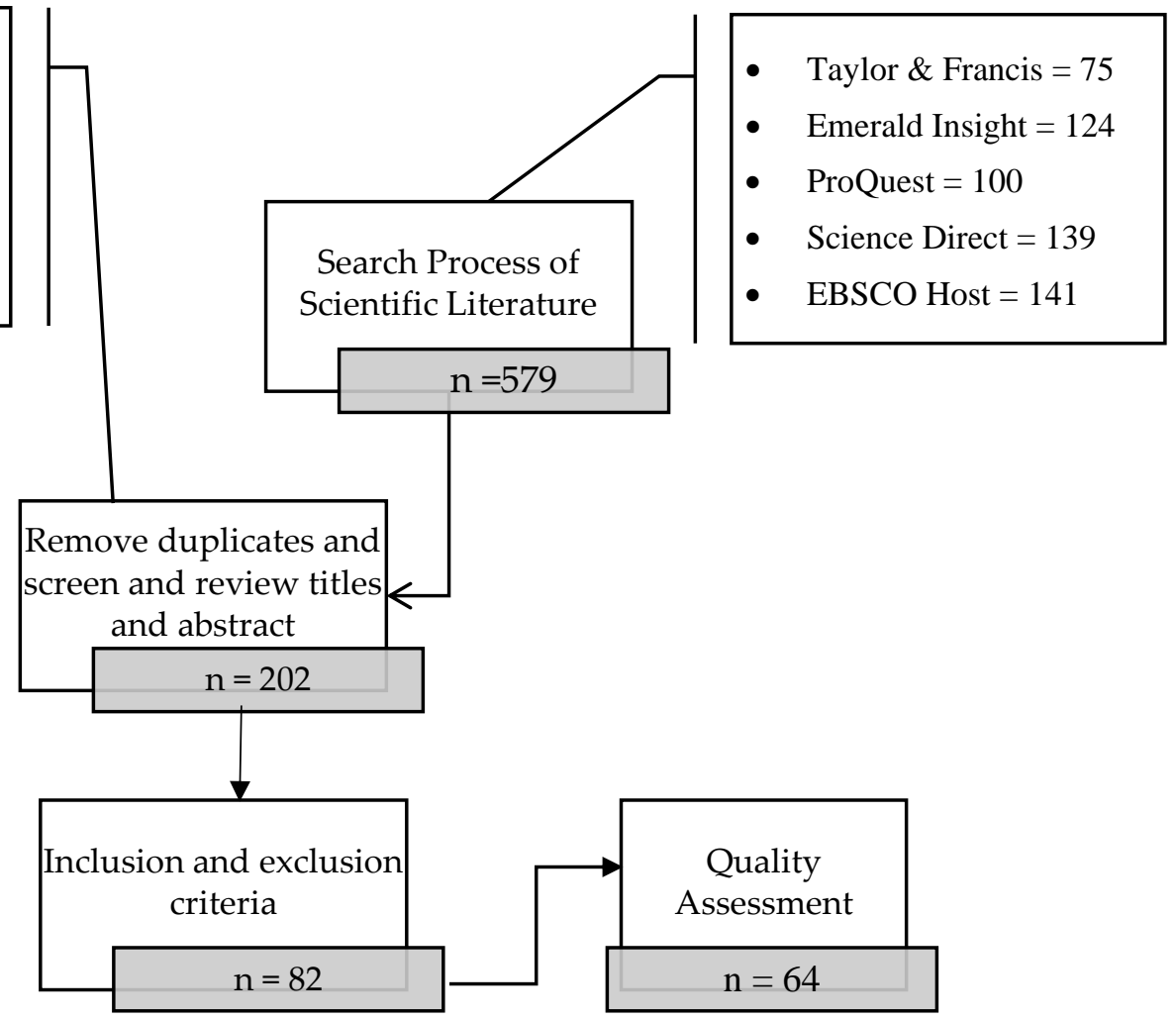

Figure 3. Stages of a systematic literature review process

\section{Data Analysis}

\subsection{Search Process}

SLR with keywords related to CSR, Sustainability Report, Upstream Oil, and Gas by searching using ProQuest, EBSCO Host, Science Direct, and Emerald databases. The purpose of this keyword search is to see how widely published the literature is regarding the sustainability report process in upstream oil and gas companies.

Based on the terms of the search criteria with keywords, the acquisition of the first search results is as follows:

Table 2. Number of publications for the selection process

\begin{tabular}{lcccccc}
\hline & $\begin{array}{l}\text { Science } \\
\text { Direct }\end{array}$ & ProQuest & $\begin{array}{l}\text { Taylor \& } \\
\text { Francis }\end{array}$ & $\begin{array}{l}\text { Emerald } \\
\text { Insight }\end{array}$ & $\begin{array}{l}\text { EBSCO } \\
\text { Host }\end{array}$ & Total \\
\hline Keywords Search & 139 & 100 & 75 & 124 & 141 & 579 \\
\hline
\end{tabular}

The total articles collected using predetermined keywords are 579 scientific articles. This result is the initial stage of the systematic literature review execution phase, namely the search process only using the suitability of keywords.

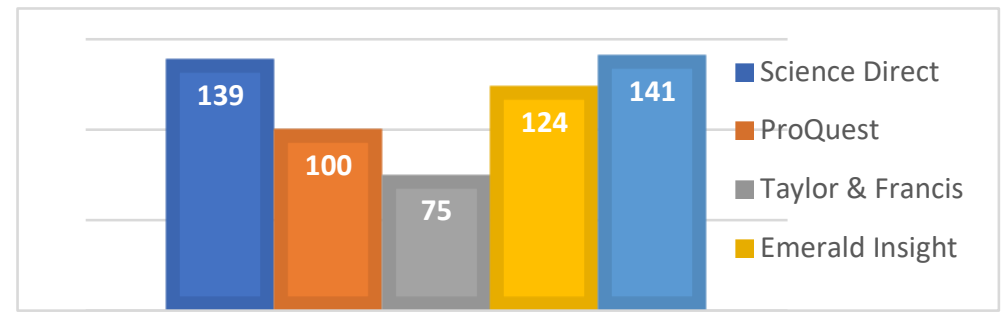

Figure 4. Search results for scientific articles based on database

Table 2 and figure 4 above show that the EBSCO Host database has search results with the most research keyword criteria with 141 articles or 24\%. Furthermore, from the search results of 579 articles, the researchers screened the suitability of titles and abstracts. 
This phase should drop several journals from the initial total of searches with keyword criteria.

The next process is selecting all scientific articles collected by searching for research suitability based on the title and abstract and dropping irrelevant or duplicated articles in more than one database.

The elimination process found as many as 377 articles with the consideration of articles that have duplication between one database and another, and the completeness of the research focus on articles that are not appropriate or incomplete. Researchers must drop articles that only discuss CSR practices and SR reporting at this selection phase but not upstream oil and gas objects. The total remaining articles are 202 articles. The following table presents the articles after the elimination process, classified based on the number of articles per database and year of publication

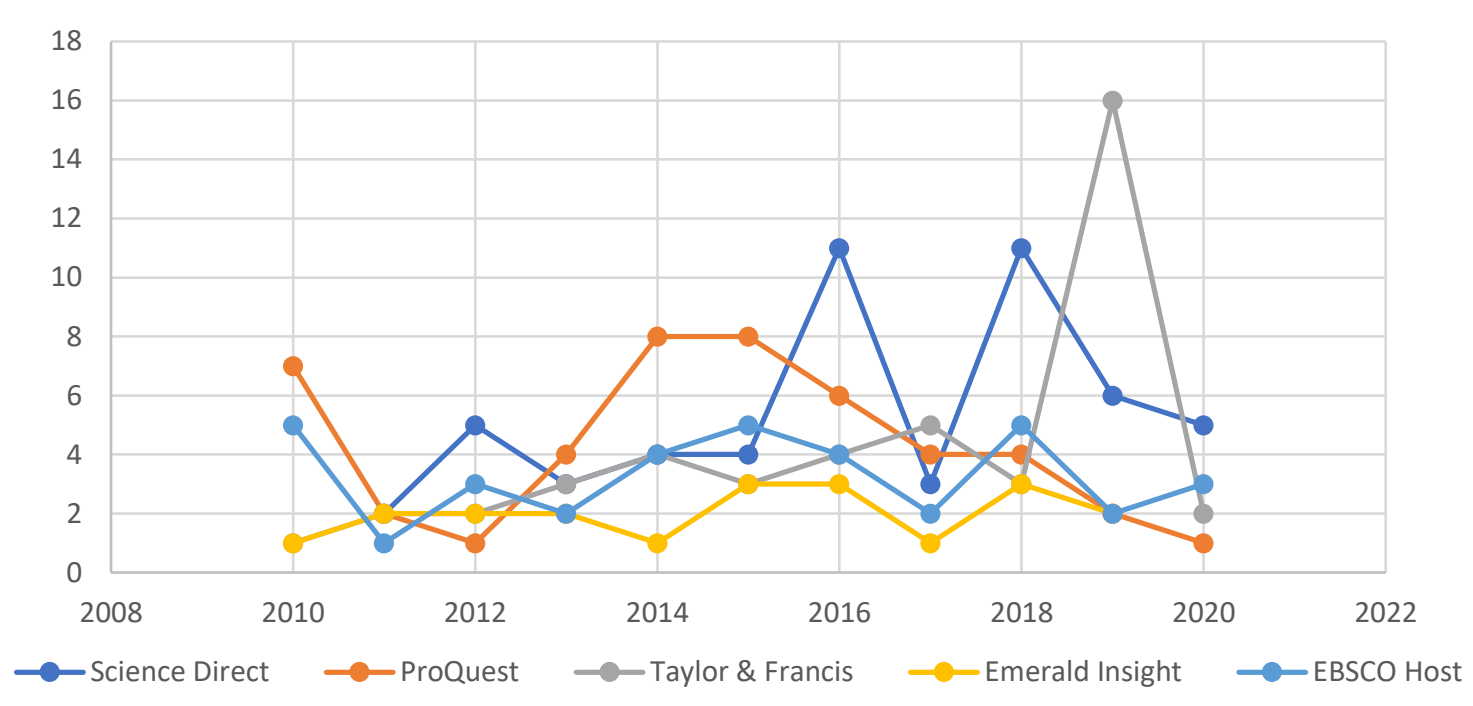

Figure 5. Number of publications per year after the screening process

This high standard qualification screening process is a common standard in SLR which implements practical and quality screening to help the examination process become more efficient and accurate by focusing on relevant articles [30].

Figure 5 above shows that of 202 scientific articles, Science Direct is the most extensive database source with 54 articles. While based on the year of publication, it is 2016 and 2019 with 28 articles each. The difference is that in 2016 the most articles came from the Science Direct database, while in 2019, most articles were from the Taylor and Francis database.

\subsection{Inclusion and Exclusion Criteria}

In the next stage, the researcher sorts the research papers based on the inclusion and exclusion criteria to know whether the data is suitable for use in this SLR research or not. This inclusion and exclusion use the following criteria:

1. The journal data used are from $2010-2020$.

2. The journal data used are from the ProQuest, EBSCO, Science Direct, Taylor \& Francis, and Emerald databases

3. The journal data relate only to the CSR and sustainability reports of upstream oil and gas industry companies.

This inclusion and exclusion phase results must drop research papers outside the CSR and SR criteria for the upstream oil and gas industry. Eliminating papers that only discuss CSR and SR and not the upstream oil and gas industry and papers relating only to the 
upstream oil and gas industry without CSR problems or SR, so the number of research papers at this stage remains 82 research papers, with the following data:

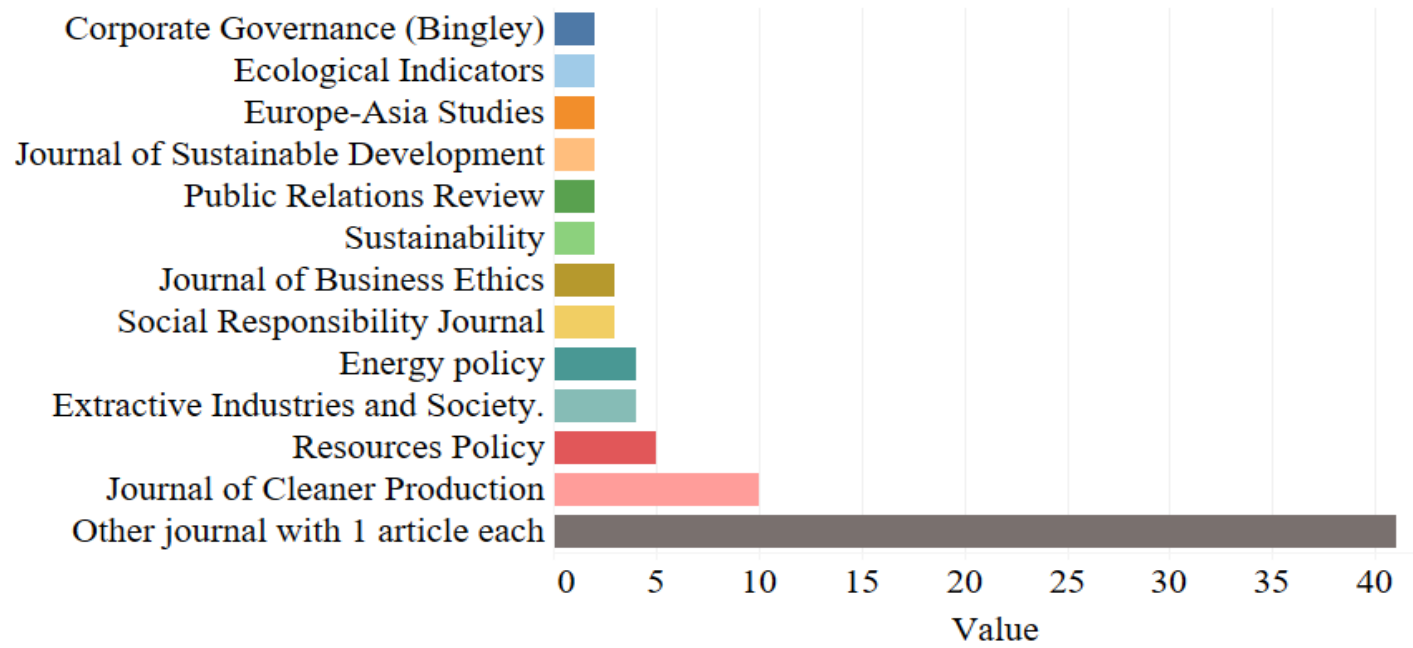

Figure 6. Results of exclusion and inclusion criteria

Figure 6 of the results of exclusion and inclusion shows that the articles come from 54 scientific journals consisting of 10 articles from the Journal of Cleaner Production, five articles from Resources Policy, four papers from Extractive Industries and Society, three articles each from Energy. Policy, Social Responsibility Journal, Journal of Business Ethics. Two articles from the Journal of Sustainability Development, Europe-Asia Studies, Ecological Indicators, Public Relations Review, Corporate Governance (Bingley) Sustainability, and 42 other scientific articles with one publication article each.

\subsection{Quality Assessment}

The third stage is the evaluation of determining the quality of the research paper to be analyzed as follows

1. Research journals published in $2010-2020$

2. Research journals that provide results related to sustainability report reliability issues

3. Research journal that discusses sustainability report reliability issues related to the upstream oil and gas industry

4. Research journals with qualifications $Q$ category and $H$ index provided that all papers fall into Q1, Q2, Q3, and Q4 and eliminate research papers outside the Q category. The number of research papers in this $Q$ category remaining is 64 research papers.

The following are the results of selecting 64 scientific articles from quality assessments based on the Q category, the Quality Assessment category. Figure 6 below shows the quality assessment results of 64 scientific papers in the period of publication from 2010 to 2020 with an assessment of the $Q$ (quartile) and H-Index categories. There are four levels of evaluation, and the first in Q1 is the assessment group for scientific articles with the highest quality, followed by Q2, Q3, and Q4. The results show that the most articles as the research object are Q1 with 43 articles, Q2 with 17 articles, Q3 with three articles, and Q4 with 1 article. 


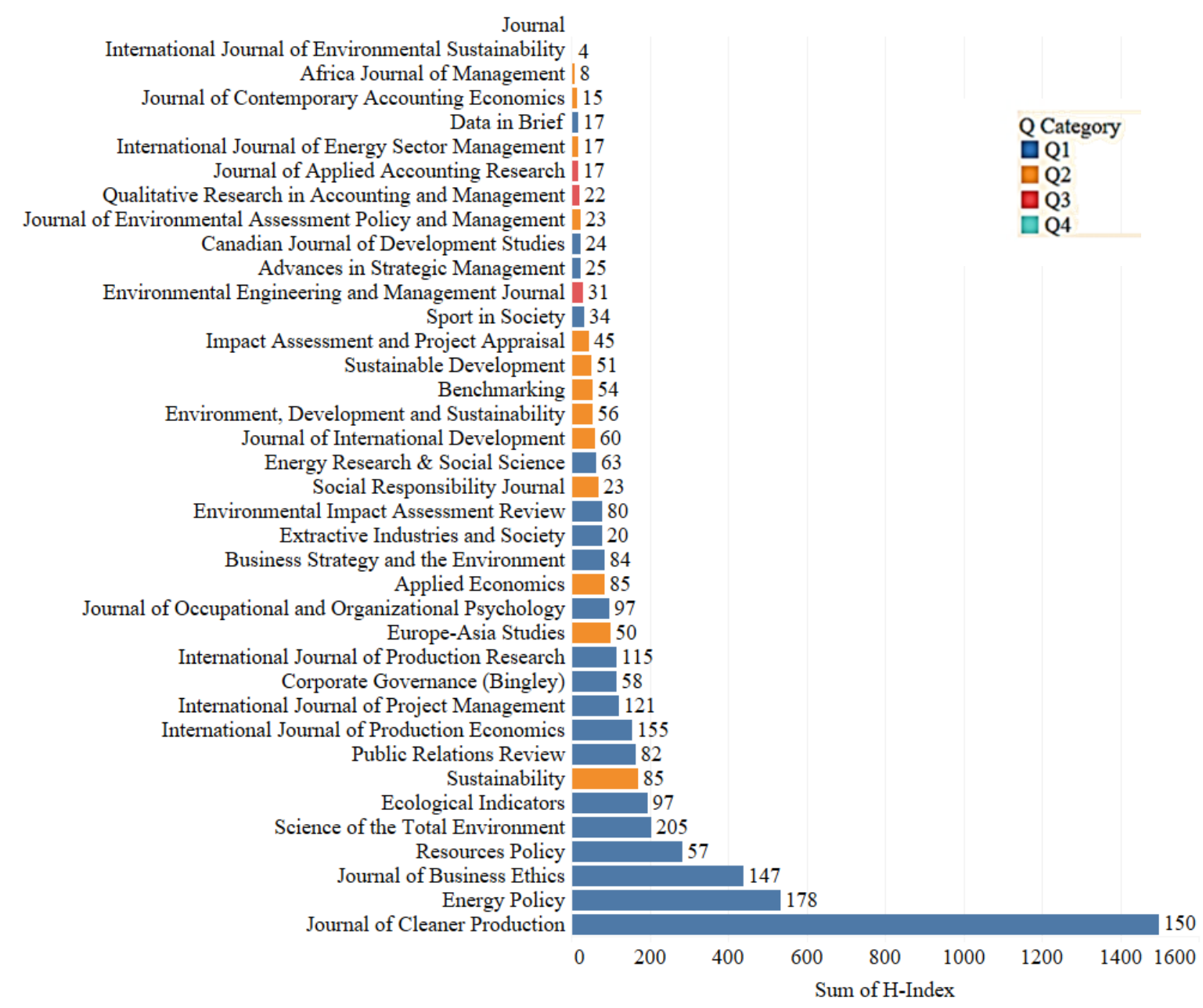

Figure 7. Quality Assessment of articles with categories Q and H-Index

Journal of Science of the Total Environment is a journal with category Q, which has the highest $\mathrm{H}$ index of 205, while the smallest $\mathrm{H}$ index is in the Journal of the International Journal of Environmental Sustainability with category Q4 and H Index of 4

\subsection{Analysis of the theoretical approach used.}

The use of fundamental theoretical analysis in selecting publications with the systematic literature review method is very varied. This variety is because the Systematic Literature Review collects research articles from several existing research methods that have differences between several journals from their practices and theories.

This analysis shows that as many as 64 articles use 19 different types of basic theory. The first and most widely used theory is Stakeholder Theory, with 19 out of 64 articles. After that, legitimacy theory with 15 articles, Institutional Theory with nine articles, Political Economy Theory with three articles, New Institutional Sociology (NIS) Theory, Resource Dependence Theory, Paradox of Plenty Theory, Social Exchange Theory, Organizational Identification Theory, Signaling Theory with two articles each. Postcolonial Theory, Elite Theory, Social Network Theory, Reciprocity Theory, Global Value Chain Theory, Business Ethics Theory, Dialectical Materialism Theory, Agency Theory, Modern Portfolio Theory each with 1 article, while as many as ten articles did not mention the specific use of theory

Stakeholder Theory is the most widely referenced theory in these 64 publications. This theory discusses how companies respond to the wishes of stakeholders to be able to carry out CSR under their expectations and the implementation of CSR that is more shareholder-oriented [13]. The following compares the use of theory in several publications that are the object of this research 


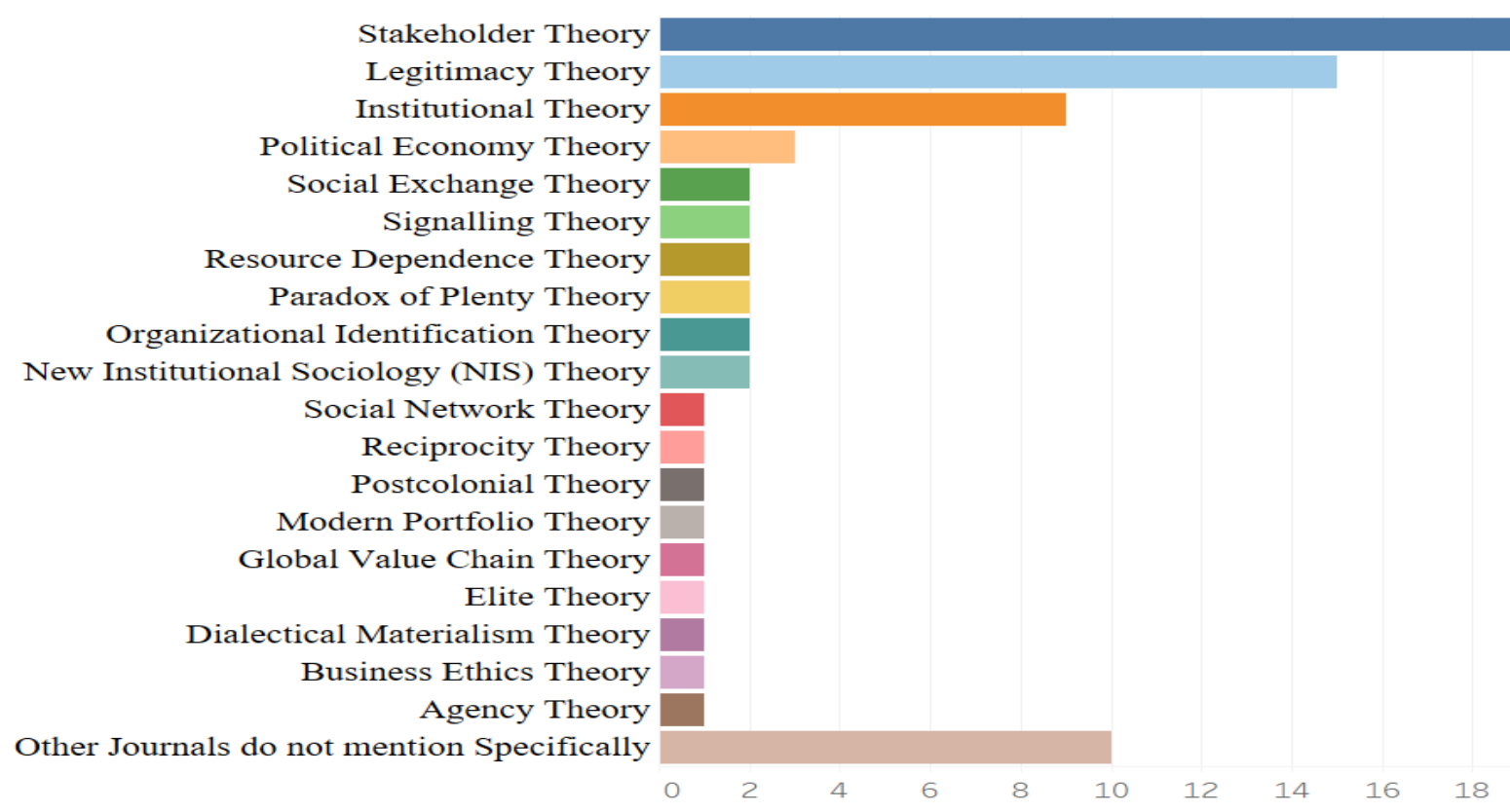

Figure 8. Grounded Theory Approach

Still related to stakeholder theory, the implementation of CSR can improve a company's reputation [31] and describe themselves as good corporate citizens[32]. The company's activities in meeting stakeholders' interests are closely related to stakeholder theory. However, if it is associated with explaining the norms in the company's operational environment, the legitimacy theory tends better. This Legitimacy Theory is the second most widely used theory in 64 research articles selected with this Systematic Literature Review

\subsection{Company Distribution Analysis}

As implementers of upstream oil and gas activities, Oil and Gas companies are parties directly involved in implementing the upstream oil and gas industry's operational activities because these companies are very vulnerable to the linkage of irregularities in CSR and SR reporting performance. The analysis at this phase shows that the global upstream oil and gas company ExxonMobil has become the object of most research related to the sustainability report bias factor, as shown in the following figure.
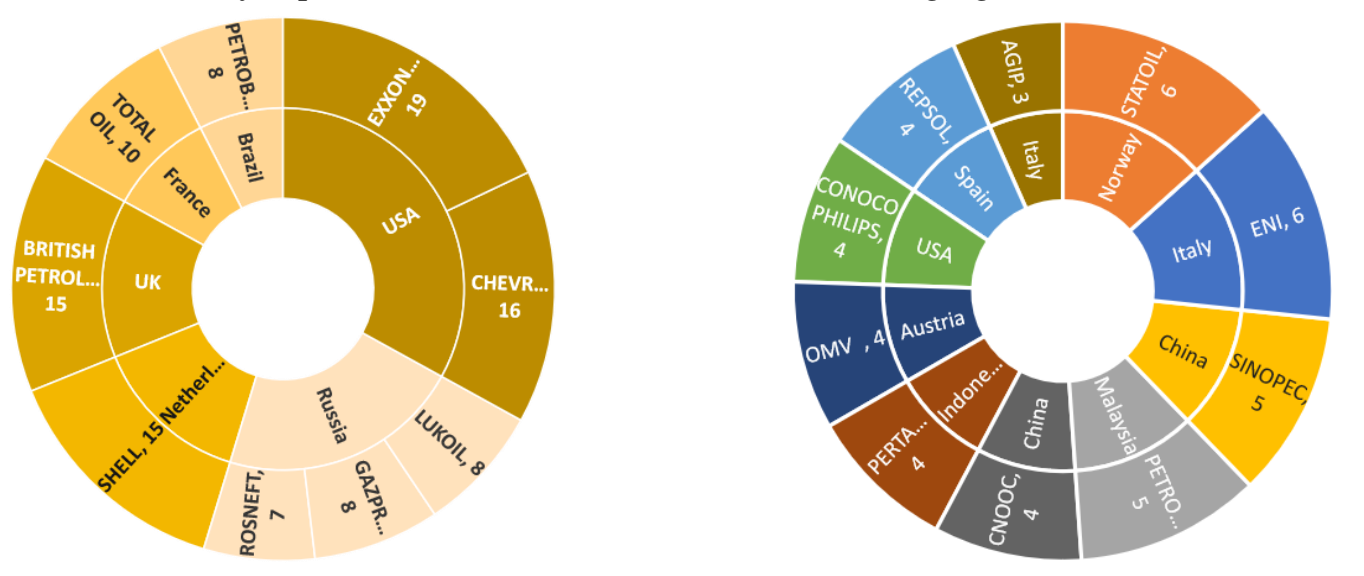

Figure 9. The first and the second top ten companies distribution analysis

Figure 9 above is the company and the country of origin cited in the scientific article that is the object of this research, namely the first top 10 and the second top 10 of the 62 companies disclosed in the scientific article. 
The first top 10 analysis revealed ExxonMobil Company in published articles 19 times out of 64 papers. The same thing is also a concern for another global upstream oil and gas company Chevron, which in this analysis reveals as a company related to CSR/SR violations as many as 16 repetitions of 64 articles. Followed by Shell and British Petroleum (BP) companies with 15 times each, Total Oil 10 times, Petrobas, Lukoil, and Gazprom 8 times each, Rosneft 7 times. While the analysis of the second top 10 shows Statoil and ENI 6 times each, Sinopec and Petronas 5 times each, Repsol, Conoco Philips, OMV, Pertamina, CNOOC 4 times each, Rusvietpetro Bashneft, Agip, ONGC, QP, Kolvaneft, and PTT 3 times each. The other companies in this scientific article are Sonatrach, Ecopetrol, Petrochina, Sino, CNPC, Marathonoil, OXY, PKN Orlen, Sasol, KNPC, and Pemex twice each, and the last is another oil and gas company with 1 article each. ExxonMobil, Chevron, Shell, and British Petroleum also have affiliates and operate in Indonesia's oil and gas exploration activities. At the same time, Pertamina is an Indonesian state-owned company that also gets repeated articles published in this systematic literature review.

\subsection{The Audit Board of the Republic of Indonesia Findings Analysis}

The Audit Board of the Republic of Indonesia/BPK (Badan Pemeriksa Keuangan) is the state agency tasked with inspecting the management and responsibility of state finances [33]. The analysis at this phase focuses on the Summary of Audit Reports Semester results (IHPS) by the BPK, the free and independent Supreme Audit Board in Indonesia. The task is to examine the management and responsibilities of state finances. Then the results of the state financial audits are submitted to the House of Representatives, Regional Representative Board, and Regional House of Representatives, under their respective authorities, followed up by representative institutions and bodies according to the law. The examination results that became the focus of the analysis were from 2016 to 2020 in the upstream oil and gas reporting section by conducting related data management, with a recapitulation of the company's findings as shown in the following figure

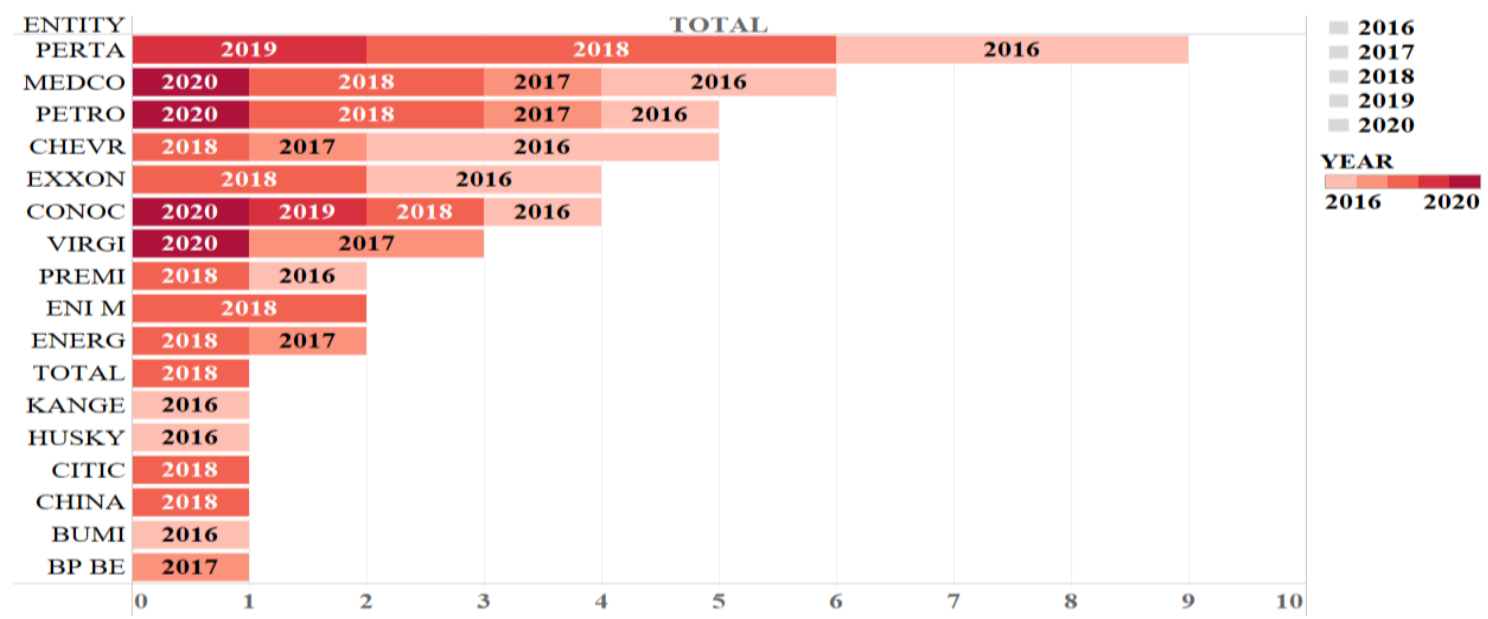

Figure 10. The Audit Board of the Republic of Indonesia audit findings

Figure 10 above shows the findings that Pertamina is the company that has been in the spotlight the most. The audit results for the last 5 years from 2016 to 2020 show that violations were committed 9 times, namely in 2016, 2018, and 2019.

This finding is in line with the systematic literature review in Fig. 9, where Pertamina is one of the companies with the frequency of committing CSR violations 4 times out of 64 
published articles. The second most inspection findings company is Medco Energi, an oil and gas company from Indonesia. The results of the analysis of the findings show 6 times, namely in 2016, 2017, 2018, and 2020, while based on the SLR, Medco Energi is a company with once results. The third highest finding was Petrochina companies, the Audit Board of the Republic of Indonesia recorded 5 violations, namely in 2016, 2017, 2018, and 2020, while the results of the Petrochina company SLR findings were twice

Chevron company became the fourth spotlight with the most findings on the results of the BPK audit, with a total of 5 findings in 2016, 2017, and 2018. Chevron became the second company with the most audit findings in the SLR analysis, with 16 findings. While Exxon Mobil based on the results of BPK audit with 4 findings in 2016 and 2018, but in SLR analysis with 19 findings is the most findings

The SLR analysis discusses the overall publications related to CSR on Oil and Gas worldwide, while the BPK findings are specifically only for violations found in Indonesia. However, the results of research at this phase can see the conclusions consistent with the SLR and the results of the BPK audit, where the results of BPK inspections in the scope of oil and gas companies in Indonesia can confirm the results of SLR analysis on global oil and gas companies that are also affiliated and operate in Indonesia

\subsection{CSR Awards Analysis}

The analysis at this stage focuses on the CSR awards of oil and gas companies for their contribution to environmental care. These companies obtained these awards from various sources and information that presented the sustainability achievements of oil and gas companies in Indonesia, received from multiple parties, both from inside or outside Indonesia, from the private sector, central government, and local governments. The following is a recapitulation summary of CSR awards for Oil and Gas companies in Indonesia

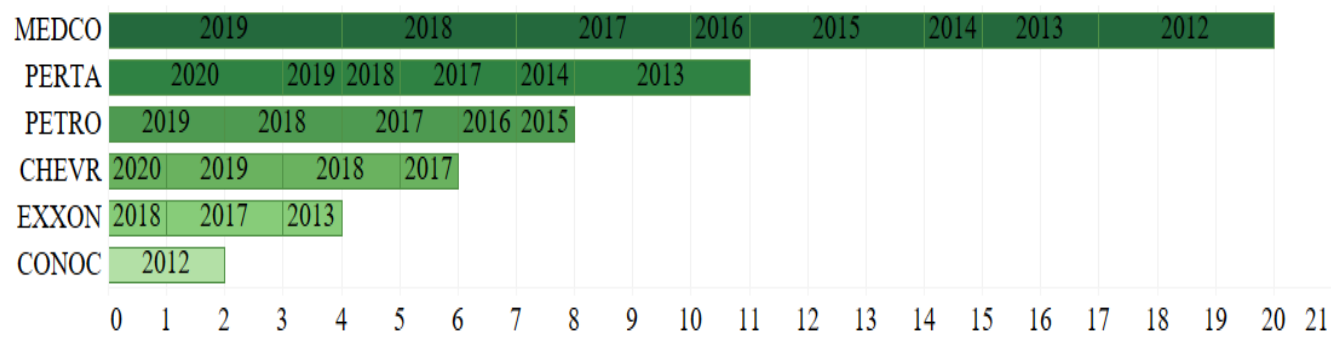

Figure 11. Sustainability award for upstream oil and gas companies in Indonesia

This figure shows that the Medco Energi company has the most sustainability achievements for 10 years from 2010 to 2020, with 20 achievements, one of which is the gold rating held by the League of American Communications Professional LLC. The same thing happened to Pertamina obtained 11 sustainability awards from various independent parties, including getting a Bronze Award for the category of Asia's Best SDG Reporting at the 6th Asia Sustainability Reporting Awards (ASRA) and a Top 10 position at the 14th International 14th Annual Corporate Register Reporting Award (CRRA) 2021

Petrochina is a global company that has oil and gas exploration activities in Indonesia. This company has achieved sustainability achievements 8 times. In 2019, received an 
award organized by the Corporate Forum for Community Development (CFCD) in collaboration with the State Minister for Chairperson of the National Development Planning Agency (Bappenas) of Indonesia. Besides Petrochina, other global upstream Oil and Gas companies also received awards for sustainability, namely Chevron and ExxonMobil. Chevron has received awards 6 times, the most recent in 2020 at the International Convention on Indonesian Upstream Oil and Gas 2020 for the Finance and Monetization category. This achievement is the highest award from SKK Migas (Special Task Force For Upstream Oil And Gas Bussiness in Indonesia) to KKKS (Oil \& Gas Contractor) for discipline in achieving oil lifting targets and efficient cost management. While Exxon Mobil received awards, in 2018 won the 2018 Indonesian SDGs Gold Award (ISDA), the Corporate Forum for Community Development (CFCD), in collaboration with the Indonesian National Development Planning Agency (Bappenas), awarded gold awards for three community development programs launched by ExxonMobil Cepu Limited (EMCL) in Bojonegoro Regency and Tuban Regency, Indonesia. The following is a comparison figure between the findings of violations based on the SLR and BPK with the acquisition of the sustainability award for upstream oil and gas companies

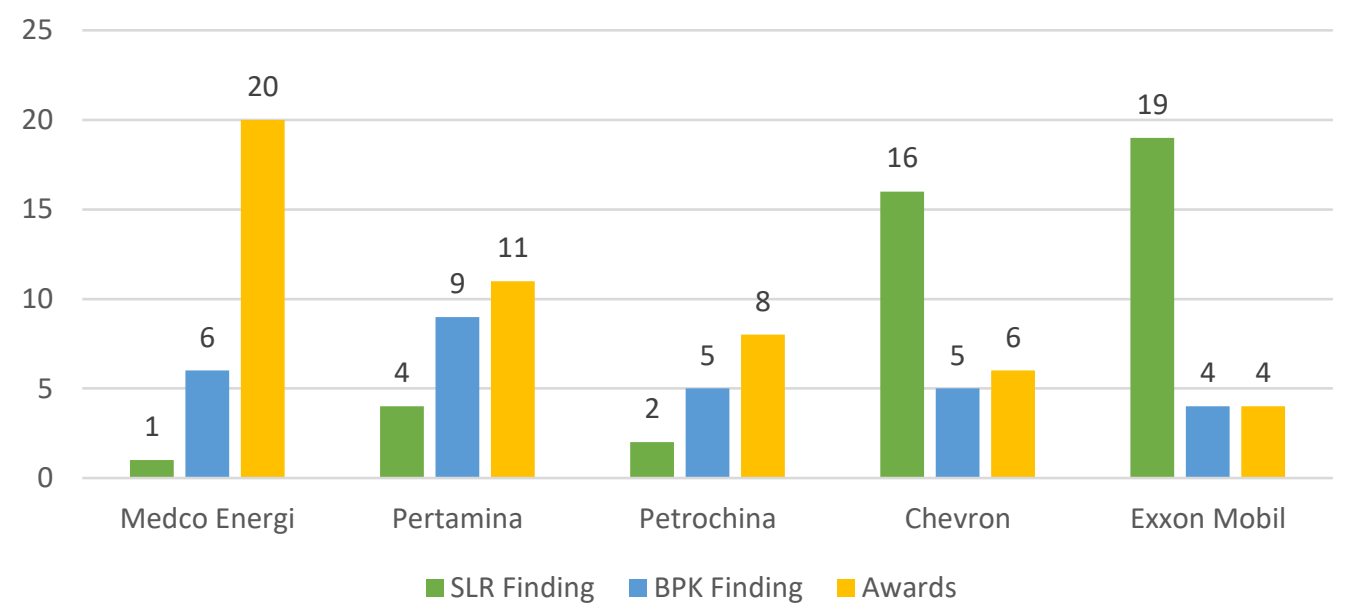

Figure 12. Comparison between the findings of violations with the award

Figure 12 shows that local upstream oil and gas companies or global upstream oil and gas companies affiliated and operating in Indonesia should report sustainability reports for their activities. These various sustainability awards show the existence of the implementation or obligation of CSR practices or sustainability reporting. But on the other hand, these companies also have findings of violations by the Indonesian state financial audit BPK. The search results based on a systematic literature review over the last 10 years also confirm irregularities in CSR practices.

CSR deviations and SR reporting are something that cannot go together, companies that commit CSR deviations should not have correct sustainability reports, but the achievements of these companies are not only reporting obligations but also get awards from various independent sustainability assessors who prestigious

In contrast, evidence of deviations and achievements of sustainability indicates that practices and processes for sustainability reporting contain bias factors. This bias can occur due to the lack of compatibility between practice and reporting that can originate from dishonest practices. There is no resistance from the community around the company for 
environmental irregularities. Even though these deviations occur based on a systematic literature review evidence and the results of the BPK inspection.

The company's ability to reduce resistance to deviations from sustainability practices indicates that the company is doing hegemony practice so that the surrounding community accepts values and a mindset without resistance. This situation occurs because the condition of the community around the exploration area improves the level of economy and income. Revenues from oil and gas rents and royalties have enriched local communities, but they have been duped into hundreds of millions of dollars in elaborate royalty schemes [34]

\section{Discussion}

\subsection{Hegemony Theory}

The irregularities and sustainability awards findings in Figure 12 show the relationship between corporate hegemony to the community and the surrounding environment. Antonio Gramsci initially put forward the idea of hegemony. This study uses hegemony to examine CSR practices and SR Reporting critically in terms of environmental care but can be biased. The concept of hegemony is beneficial for understanding the relationship of dominance from the perspective of a dominant subjectivity [35]. This critical theory provides insight into the potential bias in CSR practices and corporate SR reporting in accounting studies. There are various models of CSR practices, especially methods that support irregularities and fraud. The basic principle of hegemony is the relationship between one group and other social power groups called hegemonic. These groups get approval from different social classes and forces by creating and maintaining alliances through political and ideological struggles.[36]

In Gramsci's view, hegemony will give birth to an attitude that accepts the situation without further critical questioning. Hegemony is the influence in common sense by ideologies representing the ruling class's interests, constantly changing themselves, and incorporating contradictory and incomplete conceptions [35,37]. Hegemony occurs when the dominant regime exploits maintaining its supremacy without displaying military physical strength as a form of terror

The ongoing hegemonic power no longer presents external control because that power has internalized its object. So, it is not easy to question a problem when it is considered that something has been given consciously and present as if it were normal. Gramsci's theory of hegemony emphasizes that there is always a struggle for public acceptance in a social structure [38]. In this case, the controlling group is the upstream oil and gas company that implements the CSR program and always tries to make the people under control accept the values and mindset without resistance. In the concept of hegemony, the key to success is the simple way of thinking of the people, where the people will accept what the rulers put into their minds. Hegemony is victory through a consensus mechanism, not through the suppression of other social groups, so there is no communication to oppose or debate the decisions of the controlling party. This explanation is in line with Habermas' critical communication theory suggests that every healthy communication is communication where each participant is free to challenge. Various 
demands without fear of intimidation and the like, everyone has the same opportunity to speak, make decisions, sue, and oppose other people's opinions [39].

\subsection{Fraud Theory}

Deviations in CSR practices and SR reporting and the acquisition of sustainability awards indicate deviations in the definition of fraud proposed by Cressey [40]. This study refers to the actions taken by a group of individuals who work at oil and gas companies to commit acts of deviation from CSR practices.

Someone commits fraud when he has financial problems that cannot be resolved together or discussed with others. When he believes that he can solve problems secretly by using the position, he has to change the mindset of the initial concept as a person believed to hold assets become concepts as users of assets entrusted to them. This person realizes that their actions are illegal, but they seek to think of reasonable efforts [40], and the upstream oil and gas industry has the most significant risk to corruption, violations, and illegal [41]

There are two criteria for classifying a person as an embezzler. First, the person must accept the position of trust in good faith. Second, the person must violate the belief by committing a crime. The fraud triangle consists of three elements: pressure to commit fraud, opportunity to commit a crime, and rationalization to commit a crime, all of which must exist to commit a violation [40].

The pressure to commit fraud arises when a person can commit fraud due to unwanted financial problems and cannot discuss it with others. This pressure is a person's inability to communicate economic tensions functions as a motivation to break the law to solve problems [40]. Financial pressures arise from businesses experiencing pressures and declining investments that cause the need to steal to cover their financial shortcomings and avoid the appearance of failure [42].

The next part of the fraud triangle is the opportunity to commit the crime. The perceived opportunity to commit fraud appears when someone in a position to hold a belief violates that trust to overcome financial pressures [40]. Only those with the possibilities are logically likely to commit fraud, a white-collar crime [43].

The third part of the fraud triangle theory is the rationalization for committing crimes. Rationalization is the perpetrators' lack of feelings and indifference to justify mistakes arising from their errors [42].

The following is a conceptual model of the relationship between sustainability awards and violations committed, with supporting theories that form the basis for the formulation of this research. 


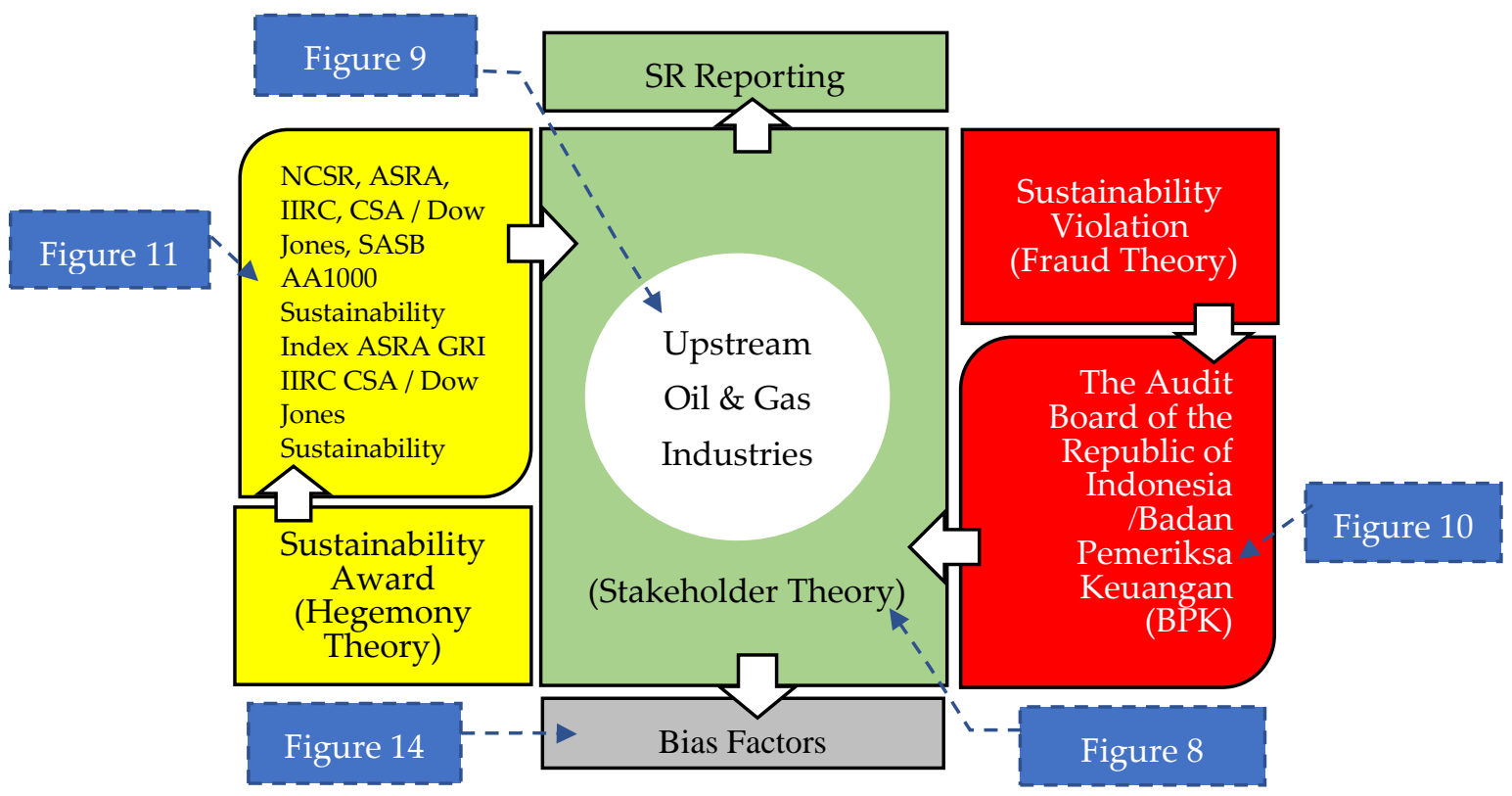

Figure 13. Conceptual model of the relationship between sustainability awards and violations

\subsection{Analysis of potential bias factors}

In this phase, the systematic literature review analyzed as many as 64 articles in the discussion and conclusion part of the article with various aspects with standard quality. At least six factors cause potential bias in implementing CSR and SR reporting in the upstream oil and gas industry. The following picture is a summary of the bias factors that occur

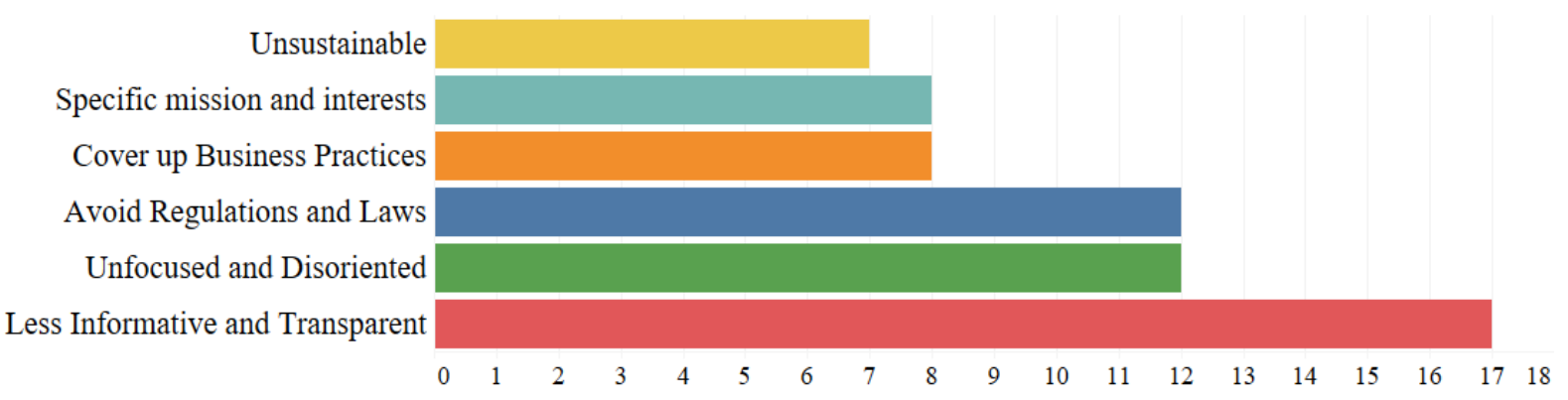

Figure 14. Potential bias analysis

The explanation of the factors causing the above potential is as follows:

1. Less informative and Transparent

The first and most classification of factors based on indicators of bias found by systematic literature review is a factor that is less informative and transparent. This factor refers to the theory of fraud, which states that a process that is not transparent will lead to potential fraud [40]. The sustainability reports of upstream oil and gas industry companies often present sustainability reports that do not meet applicable standards, such as the sustainability report format, which is only declarative, narrative, and positive [44-46]. In several Indonesian company cases, most listed companies have weaknesses in understanding corporate social and environmental disclosures [47]. They cannot provide quality social and ecological information $[48,49]$. Several oil and 
gas projects have not disclosed the low quality of environmental impact analysis to the public [50]. They tend not to be transparent and not under sustainability standards [51,52], such as significant differences between oil and gas companies regarding the definition of environmental responsibility and transparency [53]. The example of evidence in this section is BPK audit report results stated a dispute resolution case through a review mechanism by an independent consultant. This case is related to changes in the scope of work of the Banyu Urip (EPC-4) project between SKK Migas (Special Task Force for Upstream Oil and Gas Bussiness Activities Republic of Indonesia) and KKKS ExxonMobil Cepu Limited (EMCL). An independent consultant did not follow the Production Sharing Contract (PSC) in this project [54]. This discrepancy should be one aspect of the assessment in deviations from the implementation of transparent sustainability reporting.

2. Unfocused and Disoriented

The second most common factor found in these research articles is the unfocused and disoriented factor. One of the causes of this factor is a person's intention or desire to commit fraud [40]. Fraud theory can result in corporate sustainability reporting only complement [14]. There are many obstacles to put the concept of sustainability and sustainability reporting into practice [55]. These obstacles resulted in a mismatch between the objectives of governance practices and the triple bottom line concept with the environmental impact of upstream oil and gas industry companies [56,57]. In addition, The company's CSR implementation agenda rarely discusses governance failures caused by corporate actions themselves [58]. This condition causes companies to have weak commitments to integrate social and environmental sustainability, which are part of the failure to be unfocused and disoriented [59,60]. Such as the corruption case of Pertamina's CSR funds amounting to 126 billion and fraud that occurred during 2012-2014, related to the 100 million tree planting program funded by Pertamina's corporate social responsibility funds [18]. Meanwhile, according to sustainability achievement records, in 2013, Pertamina received Social Business Innovation \& Green CEO Awards 2013, Global CSR Awards 2013, and was named the Best Earth Conservation Company by Indonesia Green award also in 2013 [61]

3. Avoid regulation and law

The third most common factor found based on this systematic literature review is avoid regulation and law. This action is closely related to a person's intention to commit a violation as the fraud theory [40]. This factor shows that most of the operating activities of upstream oil and gas companies experience conflict with the surrounding community to avoid regulations and laws. [62,63]. An example of this factor is the land grabbing case in Cepu block Indonesia, which involved local elites seeking profit, including government officials, community elites, and social movement leaders [19]. In addition, there are also public protests due to illegal activities of oil and gas companies failing to carry out public consultations and mediation before carrying out well drilling operations [64]. Violations related to greenhouse emissions should be a concern for companies, violations related to human rights, bribery, and corruption practices [65-67] that should not have happened. These actions are evidence of the company's many violations and the weak regulation and legal framework in the upstream oil and gas 
industry $[68,69]$. The search based on a systematic review of the literature is in line with the evidence from BPK Audit 2015. There are indications of the arrangement for winning the auction by the tender procurement committee Number STC-0610A PT Pertamina Hulu Energi (PT PHE) Offshore North West Java (ONWJ) which resulted in no fair competition in the auction process for STC-0610A. Which could potentially lead to claims from disadvantaged vendors [70]. While the audit results of BPK audit 2016 also found non-compliance with the provisions of laws and regulations in supply chain management activities, the procurement process for goods/services was not following the requirements by Medco company E\&P Mallaca did not issue an auction cancellation announcement re-auctions that failed three times.[71]

4. Cover-up Business Practices

The fourth most common factor found based on this systematic literature review is cover-up business practices. The first, second, and third findings previously revealed that oil and gas companies committed many violations in carrying out their operations. To cover up this practice, companies take several social actions by playing sustainability actors by carrying out red-washing techniques while promoting their company's reputation [32,72]. Even CSR actions and SR reporting are carried out to save the named company from its image that causes environmental damage from its operational activities [73]. CSR will also impact performance, that the company will have a different appearance from its competitors [31]. CSR is helpful to avoid various pressures related to sustainability violations, one of which comes from media pressure [74]. In the case of land grabbing that occurred in the Cepu Block case in Bojonegoro Indonesia by ExxonMobil [19], at the same time, ExxonMobil intensively carried out the CSR program "Empowering Women through Technology Distribution," in the category "Micro Loans Empowering Indonesian Women" to obtain Corporate Social Responsibility (CSR) Award 2013 organized by Sindo News in partnership with the Coordinating Ministry for People's Welfare, Ministry of Social Affairs and Ministry of Women's Empowerment and Child Protection

5. Specific Mission and Interest

Mission and Special Interests were the fifth most common factors found in the literature review section of this systematic research. When the law has detected an act of violation, fraud, and cheating, usually the perpetrator will provide a rational reason as a form of self-defence. [40]. This rationalization occurs with the intention that the error is a natural action to be carried out as a mission and interest. Many activities and interventions have a limiting interest in implementing sustainability [75,76]. Such that CSR is often considered an obstacle to achieving maximum profit for the company [77]. The company carries out CSR activities and SR reporting to get awards from sustainability assessment institutions to attract investors. Most of these actions are carried out by the board of directors and shareholders, who influence decisions. They also affect the results of reports on sustainability practices carried out by companies $[30,78]$. In composing the HPS (Self Estimated Price), the procurement of spare parts for the Hitachi gas turbine at the KKKS Petrochina International Jabung (PCJL) is considered inaccurate. The HPS value used is only based on references from one vendor 
who is not the sole agent [71]. This action indicates a particular interest carried out that is contrary to the principle of sustainability.

6. Unsustainable

The last finding in the literature review section is unsustainable action. This unsustainable concept is not under the aspect of sustainability. The company takes measures regarding the opportunities for fraud and violations during the implementation of CSR. The reporting process usually has an impact on the occurrence of unsustainable practices. In some fraud theories, opportunities are used that are the most likely to be minimized $[40,79,80]$ through continuous application consisting of processes, procedures, and controls. However, in companies that do not apply the concept of sustainability, which is only carried out at certain times, it can result in CSR implementation, which tends not to run consistently [16], thus creating opportunities for deviations and violations. Many companies believe that CSR practices and SR reporting are not part of the sustainability strategy that companies must implement in the long term [81]. Another finding is that the implementation of sustainability practices as a whole has not been entirely carried out by oil and gas companies [82]. Resulting in no relationship of mutual trust between industry, government, and society [64] and is an unsustainable matter. Various findings of violations of the sustainability of upstream oil and gas companies have resulted in sustainability reporting and sustainability achievements that have been carried out to be unsustainable because the various sustainability actions are only temporary.

\section{Conclusions}

This research has an academic contribution to the conclusions of research results based on topics selected, studied, and proven by previous researchers. The results of this study can identify, evaluate, and interpret all relevant research results. Systematic literature reviews provide different research results and use a different process than some other research methods. This research draws on many previous studies that used various methods such as surveys, experiments with quantitative or qualitative approaches to produce an accurate synthesis. The selection of research papers that become the object of this research uses a qualification stage with techniques that can account for quality. Another contribution is identifying the literature to verify the actual bias factor in CSR activities and the sustainability achievements of upstream oil and gas companies in SR reporting. Verification of evidence related to findings of potential bias in CSR practices and SR reporting in each manuscript to conclude potential bias in sustainability reporting in global and local upstream oil and gas companies in Indonesia

In addition, the findings of BPK audit report regarding violations of upstream oil and gas companies operating in Indonesia confirm the results with a systematic review of the literature. The achievement and award of sustainability of upstream oil and gas companies should not occur if the company concerned is still dealing with problems of law violations, governance, and deviation from other aspects of sustainability

Hegemony theory can explain the relationship between violations that occur with the achievement of sustainability achievements, where companies can make the surrounding community accept values and a concept without resistance. This situation 
occurs because the condition of the community around the exploration area improves at the economic level with the presence of upstream oil and gas companies that also commit various sustainability deviations.

This deviation follows the Fraud Theory in the concept of opportunity, pressure, and rationalization, where the oil and gas industry is vulnerable to deviant practices and even corruption. This fraud theory also supports the results of this study related to the pressure to commit fraud. The results show that the stakeholder theory is the most widely used. This theory discusses how companies respond to the wishes of stakeholders in carrying out CSR and SR reporting. This result is one form of pressure in the fraud triangle theory that companies receive to meet stakeholder expectations. However, some companies still carry out their activities related to potentially biased matters. The aspect of opportunities for violating CSR practices is one of the determining factors for someone who has a role in the company gaining trust to carry out the wishes of stakeholders. In addition, rationalization also proves that the findings of violations in the analysis of scientific journal manuscripts assume justification for committing violations. Based on a systematic critical review of the literature review, there are at least six factors of sustainability reporting bias, namely Less informative and Transparent, Unfocused and Disoriented, Avoid regulation and law, Cover-up Business Practices, Specific Mission and Interest, and Unsustainable.

$\begin{array}{ll}\text { Abbreviation } & \\ \text { BPK } & \text { : Badan Pemeriksa Keuangan (The Audit Board of the Republic of } \\ & \text { Indonesia) } \\ \text { CSR } & \text { : Corporate Social Responsibility } \\ \text { SR } & : \text { Sustainability Reports } \\ \text { KKKS } & \text { : Kontraktor Kontrak Kerjasama (Oil \& Gas Contractor) } \\ \text { GRI } & : \text { Global Reporting Initiative } \\ \text { PSC } & \text { : Production Sharing Contract } \\ \text { NCSR } & \text { : National Center for Sustainability Reporting } \\ \text { IIRC } & : \text { International Integrated Reporting Council } \\ \text { SASB } & : \text { Sustainability Accounting Standards Board } \\ \text { IHPS } & : \text { Ihtisar Hasil Pemeriksaan Semester (Summary of Audit Reports } \\ & \text { Semester) } \\ \text { SKK Migas } & : \text { Satuan Kerja Khusus Pelaksana Kegiatan Usaha Hulu Minyak dan } \\ & \text { Gas Bumi (Special Task Force For Upstream Oil and Gas Bussiness } \\ & \text { in Indonesia) } \\ \text { Bappenas } & : \text { Badan Perencanaan Pembangunan Nasional (Indonesian National } \\ & \text { Development Planning Agency) } \\ \text { EMCL } & : \text { ExxonMobil Cepu Limited } \\ \text { PHE ONWJ } & : \text { Pertamina Hulu Energi Offshore North West Java } \\ \text { HPS } & : \text { Harga Perkiraan Sendiri (Self Estimated Price) } \\ \text { PCJL } & : \text { Petrochina International Jabung } \\ & \end{array}$


Author Contributions: All authors contributed to this research. FK performed designs and developed the first draft of this manuscript in research ideas. NN supervises providing input on the references. HS analyzes the appropriateness of the methodology during the analysis process, MD analyzes the suitability of the use of theory, All authors have read and agreed to the published version of the manuscript

Funding: This research received no external funding

Data Availability Statement: Not Applicable

Acknowledgments: The authors acknowledge and are grateful for the support from Mercu Buana University, Jakarta Indonesia, and Padjadjaran University Bandung, Indonesia, for the opportunity to complete this research

Conflicts of Interest: The authors declare that they have no known competing financial interests or personal relationships that could have appeared to influence the work reported in this paper.

\section{References}

1. Mata, C.; Fialho, A.; Eugénio, T. A decade of environmental accounting reporting: what we know? Journal of Cleaner Production 2018, 198, 1198-1209, doi:10.1016/j.jclepro.2018.07.087.

2. Paun, D. Corporate sustainability reporting: An innovative tool for the greater good of all. Journal of Business Horizons 2018, 61, 925-935, doi:10.1016/j.bushor.2018.07.012.

3. Putrevu, S.; McGuire, J.; Siegel, D.S.; Smith, D.M. Corporate social responsibility, irresponsibility, and corruption: Introduction to the special section. Journal of Business Research 2012, 65, 1618-1621, doi:10.1016/j.jbusres.2011.10.020.

4. Aras, G.; Crowther, D. The durable corporation: Strategies for sustainable development; Routledge: 2016.

5. Raufflet, E.; Cruz, L.B.; Bres, L. An assessment of corporate social responsibility practices in the mining and oil and gas industries. Journal of Cleaner production 2014, 84, 256-270, doi:10.1016/j.jclepro.2014.01.077.

6. Ebiringa, O., Yadirichukwu, Emeh, Chigbu, E. Ogochukwu, Obi Joseph. Effect of firm size and profitability on corporate social disclosures: The Nigerian oil and gas sector in Focus. British Journal of Economics, Management $\mathcal{E}$ Trade 2013, 3, 563-574, doi:10.9734/BJEMT/2013/5147.

7. Elhuni, R.M.; Ahmad, M.M. Key performance indicators for sustainable production evaluation in oil and gas sector. Procedia Manufacturing 2017, 11, 718-724, doi:10.1016/j.promfg.2017.07.172.

8. Branco, M.C.; Matos, D. The fight against corruption in Portugal: evidence from sustainability reports. Journal of Financial Crime 2016, doi:10.1108/JFC-05-2014-0027.

9. Boiral, O. Sustainability reports as simulacra? A counter-account of A and A+ GRI reports. Accounting, Auditing Accountability Journal 2013, doi:10.1108/AAAJ-04-2012-00998.

10. PwC, I. Oil and Gas in Indonesia. Investment and Taxation Guide 2019 - 10th Edition. Available online: https://www.pwc.com/id/en/pwc-publications/industries-publications/energy--utilities---mining-publications/oilgas-guide-2019.html (accessed on March 21).

11. PwC, I. Oil and Gas in Indonesia Investment and Taxation Guide 2020 - 11th Edition. Available online: https://www.pwc.com/id/en/pwc-publications/industries-publications/energy--utilities---mining-publications/oilgas-guide-2020.html (accessed on March 21).

12. Law of the Republic of Indonesia Number 40 of 2007 Concerning Limited Liability Companies. 2007. 
13. Fifka, M.S.; Drabble, M. Focus and standardization of sustainability reporting-a comparative study of the United Kingdom and Finland. Journal of Business Strategy the Environment 2012, 21, 455-474, doi:10.1002/bse.

14. Cash, A.C. Corporate social responsibility and petroleum development in sub-Saharan Africa: The case of Chad. Resources Policy 2012, 37, 144-151, doi:10.1016/j.resourpol.2011.08.001.

15. Gardner, K.; Ahmed, Z.; Bashir, F.; Rana, M. Elusive partnerships: Gas extraction and CSR in Bangladesh. Resources Policy 2012, 37, 168-174, doi:10.1016/j.resourpol.2012.01.001.

16. Tuulentie, S., Halseth, G., Kietäväinen, A., Ryser, L., \& Similä, J. . Local community participation in mining in Finnish Lapland and Northern British Columbia, Canada-Practical applications of CSR and SLO. . Resources Policy 2019, Volume 61, June 2019, 99-107, doi:10.1016/j.resourpol.2019.01.015.

17. ICTJ. Kasus Keterlibatan? Exxon Mobil di Pengadilan karena Perannya dalam Pelanggaran Hak Asasi Manusia di Aceh. 2001.

18. Handoko, D.T. Korupsi CSR Pertamina, Bareskrim Temukan Relawan Fiktif. Tempo 2 September 20152015.

19. Bachriadi, D.; Suryana, E. Land grabbing and speculation for energy business: a case study of ExxonMobil in East Java, Indonesia. Canadian Journal of Development Studies/Revue canadienne d'études du développement 2016, 37, 578-594, doi:10.1080/02255189.2016.1197825.

20. Wijayanto, N. SKK Migas Terima Sustainability Reporting Award 2014. sindonews.com 2014.

21. Hariyanto. Ungguli Ratusan Perusahaan Dari 17 Negara di Asia, Pertamina Sabet Bronze Award di Ajang ASRA ke 6. Industri.co.id 2021.

22. Suharto, E. CSR \& COMDEV Investasi kreatif perusahaan di era globalisasi; Alfabeta Bandung, 2010.

23.Newman, I.; Benz, C.R.; Ridenour, C.S. Qualitative-quantitative research methodology: Exploring the interactive continuum; SIU Press: 1998.

24. Denzin, N.K.; Lincoln, Y.S. The Sage handbook of qualitative research; sage: 2011.

25. Van Leeuwen, T. Critical discourse analysis. The international encyclopedia of language social interaction 2015, 1-7.

26. Van Leeuwen, T. The representation of social actors. In Texts and practices; Routledge: 2013; pp. 41-79.

27. Delgado-Rodríguez, M.; Sillero-Arenas, M. Systematic review and meta-analysis. Medicina Intensiva (English Edition) 2018, 42, 444-453, doi:10.1016/j.medin.2017.10.003.

28. Chandler, J.; Cumpston, M.; Li, T.; Page, M.J.; Welch, V.A. Cochrane handbook for systematic reviews of interventions; John Wiley \& Sons: 2019.

29. Gough, D.; Oliver, S.; Thomas, J. An introduction to systematic reviews; Sage: 2017.

30. Agudelo, M.A.L.; Johannsdottir, L.; Davidsdottir, B. Drivers that motivate energy companies to be responsible. A systematic literature review of Corporate Social Responsibility in the energy sector. Journal of Cleaner Production 2020, 247, 119094, doi:10.1016/j.jclepro.2019.119094.

31. Hansen, M.W. Toward a strategic management perspective on local content in African extractives: MNC procurement strategies between local responsiveness and global integration. Africa Journal of Management 2020, 6, 2442, doi:10.1080/23322373.2020.1717283.

32. Millington, R.; Giles, A.R.; Hayhurst, L.M.; van Luijk, N.; McSweeney, M. 'Calling out'corporate redwashing: the extractives industry, corporate social responsibility and sport for development in indigenous communities in Canada. Sport in Society 2019, 22, 2122-2140, doi:10.1080/17430437.2019.1567494.

33. Law of The Republic of Indonesia Number 15 of 2006 Concerning The Audit Board of the Republic of Indonesia. 2006.

34. Ruddell, R. Oil, gas, and crime: The dark side of the boomtown; Springer: 2017.

35. Furnaro, A. Hegemony and passivity in mining regions: Containing dissent in north-central Chile. The Extractive Industries Society 2019, 6, 215-222, doi:10.1016/j.exis.2018.07.009

36. Gramsci, A. Hegemony; na: 1971. 
37. Loftus, A. Time for Gramsci. In In: Bryant, R.L (ED), The International Handbook of Political Ecology; Edward Edgar Publishing: Cheltenham, UK. Northampton, MA, USA, 2015; Volume pp. 89-102.

38. Bates, T.R. Gramsci and the Theory of Hegemony. Journal of the History of Ideas 1975, 36, 351-366.

39. German, K.M. Critical theory in public relations inquiry: Future directions for analysis in a public relations context. Public relations inquiry as rhetorical criticism 1995, 279-294.

40. Cressey, D.R. Other people's money; a study of the social psychology of embezzlement. The Journal of Criminal Law, Criminology, and Police Science, 1953, Vol. 45, No. 4 pp. 464-465.

41. Ibrahim, B.; Robey, T. Mapping corruption risk in Indonesia's upstream oil and gas industry. 2020.

42. Dellaportas, S. The effect of a custodial sentence and professional disqualification on reintegration. J Critical Perspectives on Accounting 2014, 25, 671-682, doi:10.1016/j.cpa.2014.03.005.

43. Schuchter, A.; Levi, M. Beyond the fraud triangle: Swiss and Austrian elite fraudsters. In Proceedings of the Accounting Forum, 2015; pp. 176-187.

44. Dong, S.; Burritt, R. Cross - sectional benchmarking of social and environmental reporting practice in the australian oil and gas industry. Sustainable Development 2010, 18, 108-118, doi:10.1002/sd.450.

45. Junior, F.H.; Galleli, B.; Gallardo-Vázquez, D.; Sánchez-Hernández, M.I. Strategic aspects in sustainability reporting in oil \& gas industry: The comparative case-study of Brazilian Petrobras and Spanish Repsol. Ecological indicators 2017, 72, 203-214, doi:10.1016/j.ecolind.2016.08.007.

46. Wan Ahmad, W.N.K.; de Brito, M.P.; Tavasszy, L.A. Sustainable supply chain management in the oil and gas industry: a review of corporate sustainability reporting practices. Benchmarking: An International Journal 2016, 23, 1423-1444, doi:10.1108/BIJ-08-2013-0088.

47. Gery Djajadikerta, H.; Trireksani, T. Corporate social and environmental disclosure by Indonesian listed companies on their corporate web sites. Journal of applied accounting research 2012, 13, 21-36, doi:10.1108/09675421211231899.

48. Anifowose, B.; Lawler, D.M.; van der Horst, D.; Chapman, L. A systematic quality assessment of Environmental Impact Statements in the oil and gas industry. Science of the Total Environment 2016, 572, 570-585, doi:10.1016/j.scitotenv.2016.07.083.

49. Frank, A.G.; Dalle Molle, N.; Gerstlberger, W.; Bernardi, J.A.B.; Pedrini, D.C. An integrative environmental performance index for benchmarking in oil and gas industry. Journal of cleaner production 2016, 133, 1190-1203, doi:10.1016/j.jclepro.2016.06.064.

50. Aung, T.S.; Shengji, L.; Condon, S. Evaluation of the environmental impact assessment (EIA) of Chinese EIA in Myanmar: Myitsone Dam, the Lappadaung Copper Mine and the Sino-Myanmar oil and gas pipelines. Impact Assessment Project Appraisal 2019, 37, 71-85, doi:10.1080/14615517.2018.1529948.

51. Dura, C.C.; Drigă, I.; Isac, C. Environmental reporting by oil and gas multinationals from Russia and Romania: A comparative analysis. Environmental Engineering Management Journal 2017, 16.

52. George, R.A.; Siti-Nabiha, A.; Jalaludin, D.; Abdalla, Y.A. Barriers to and enablers of sustainability integration in the performance management systems of an oil and gas company. Journal of cleaner production 2016, 136, 197-212, doi:10.1016/j.jclepro.2016.01.097.

53. Shvarts, E.A.; Pakhalov, A.M.; Knizhnikov, A.Y. Assessment of environmental responsibility of oil and gas companies in Russia: the rating method. Journal of Cleaner Production 2016, 127, 143-151, doi:10.1016/j.jclepro.2016.04.021.

54. BPK. Summary of Audit Reports Semester II; The Audit Board of the Republic of Indonesia: Jakarta, 2016; pp. 238-239.

55. Gardas, B.B.; Mangla, S.K.; Raut, R.D.; Narkhede, B.; Luthra, S.J.J.o.C.P. Green talent management to unlock sustainability in the oil and gas sector. 2019, 229, 850-862, doi:10.1016/j.jclepro.2019.05.018. 
56. De Roeck, K.; Delobbe, N. Do environmental CSR initiatives serve organizations' legitimacy in the oil industry? Exploring employees' reactions through organizational identification theory. Journal of business ethics 2012, 110, 397412, doi:10.1007/s10551-012-1489-x.

57. Infante, C.E.D.d.C.; de Mendonça, F.M.; Purcidonio, P.M.; Valle, R. Triple bottom line analysis of oil and gas industry with multicriteria decision making. Journal of Cleaner Production 2013, 52, 289-300, doi:10.1016/j.jclepro.2013.02.037.

58. Frynas, J.G. Corporate social responsibility and societal governance: Lessons from transparency in the oil and gas sector. Journal of business ethics 2010, 93, 163-179, doi:10.1007/s10551-010-0559-1.

59. Marnewick, C. Information system project's sustainability capabality levels. International Journal of Project Management 2017, 35, 1151-1166, doi:10.1016/j.ijproman.2017.02.014.

60. Yusuf, Y.Y.; Gunasekaran, A.; Musa, A.; El-Berishy, N.M.; Abubakar, T.; Ambursa, H.M. The UK oil and gas supply chains: An empirical analysis of adoption of sustainable measures and performance outcomes. International Journal of Production Economics 2013, 146, 501-514.

61. Social Responsibility Awards. Available online: https://www.pertamina-ptc.com/csr/penghargaan/ (accessed on August, 12).

62. Hassan, A.; Kouhy, R. From environmentalism to corporate environmental accountability in the Nigerian petroleum industry: do green stakeholders matter? International Journal of Energy Sector Management 2015, 9, 204-226, doi:10.1108/IJESM-05-2014-0008.

63. Henry, L.A.; Nysten-Haarala, S.; Tulaeva, S.; Tysiachniouk, M. Corporate social responsibility and the oil industry in the Russian Arctic: Global norms and neo-paternalism. Europe-Asia Studies 2016, 68, 1340-1368, doi:10.1080/09668136.2016.1233523.

64.Wilson, E.; Istomin, K. Beads and Trinkets? Stakeholder Perspectives on Benefit-sharing and Corporate Responsibility in a Russian Oil Province. Europe-Asia Studies 2019, 71, 1285-1313, doi:10.1080/09668136.2019.1641585.

65. Kirat, M. Corporate social responsibility in the oil and gas industry in Qatar perceptions and practices. Public Relations Review 2015, 41, 438-446, doi:10.1016/j.pubrev.2015.07.001.

66.Krishnamurti, C.; Shams, S.; Velayutham, E. Corporate social responsibility and corruption risk: A global perspective. Journal of Contemporary Accounting Economics 2018, Vol 14, 1-21, doi:10.1016/j.jcae.2018.02.002.

67. Chaiyapa, W.; Esteban, M.; Kameyama, Y. Sectoral approaches establishment for climate change mitigation in Thailand upstream oil and gas industry. Energy Policy 2016, 94, 204-213, doi:10.1016/j.enpol.2016.04.007.

68. Graham, E.; Ovadia, J.S. Oil exploration and production in Sub-Saharan Africa, 1990-present: trends and developments. The Extractive Industries Society 2019, doi:10.1016/j.exis.2019.02.001.

69. Schneider, J.; Ghettas, S.; Merdaci, N.; Brown, M.; Martyniuk, J.; Alshehri, W.; Trojan, A. Towards sustainability in the oil and gas sector: benchmarking of environmental, health, and safety efforts. Journal of Environmental Sustainability 2013, 3, 6.

70. BPK. Summary of Audit Reports Semester I; The Audit Board of the Republic of Indonesia: Jakarta, 2015 ; p. 128.

71. BPK. Summary of Audit Reports Semester I The Audit Board of the Republic of Indonesia: Jakarta, $2016 ;$ p. 182.

72. Sandberg, M.; Holmlund, M. Impression management tactics in sustainability reporting. Social Responsibility Journal 2015, 11, 677-689, doi:10.1108/SRJ-12-2013-0152.

73. Tang-Lee, D. Corporate social responsibility (CSR) and public engagement for a Chinese state-backed mining project in Myanmar-Challenges and prospects. Resources Policy 2016, 47, 28-37, doi:10.1016/j.resourpol.2015.11.003.

74. Nazari, J.A.; Herremans, I.M.; Warsame, H.A. Sustainability reporting: External motivators and internal facilitators. Corporate Governance 2015, 15, 375-390, doi:10.1108/CG-01-2014-0003.

75. Inkpen, A.; Ramaswamy, K. State-Owned Multinationals and Drivers of Sustainability Practices: An Exploratory Study of National Oil Companies. In Sustainability, Stakeholder Governance, and Corporate Social Responsibility; Emerald Publishing Limited: 2018; pp. 95-117. 
76. Lamorgese, L.; Geneletti, D.; Partidario, M.R. Reviewing strategic environmental assessment practice in the oil and gas sector. Journal of Environmental Assessment Policy and Management 2015, 17, 1550017, doi:10.1142/S1464333215500179.

77. Ngai, E.; Law, C.C.; Lo, C.W.; Poon, J.; Peng, S. Business sustainability and corporate social responsibility: case studies of three gas operators in China. International Journal of Production Research 2018, 56, 660-676, doi:10.1080/00207543.2017.1387303.

78. Mahmood, M.; Orazalin, N. Green governance and sustainability reporting in Kazakhstan's oil, gas, and mining sector: Evidence from a former USSR emerging economy. Journal of cleaner Production 2017, 164, 389-397, doi:10.1016/j.jclepro.2017.06.203.

79. Goldstraw-White, J. White-collar crime: Accounts of offending behaviour; Springer: 2011.

80. Wolfe, D.T.; Hermanson, D.R. The fraud diamond: Considering the four elements of fraud. 2004.

81.Shad, M.K.; Lai, F.-W.; Fatt, C.L.; Klemeš, J.J.; Bokhari, A. Integrating sustainability reporting into enterprise risk management and its relationship with business performance: A conceptual framework. Journal of Cleaner production 2019, 208, 415-425, doi:10.1016/j.jclepro.2018.10.120.

82. Abdulrahman, A.O.; Huisingh, D.; Hafkamp, W. Sustainability improvements in Egypt's oil \& gas industry by implementation of flare gas recovery. Journal of Cleaner Production 2015, 98, 116-122, doi:10.1016/j.jclepro.2014.11.086. 